\title{
Implementasi Pendidikan Mitigasi Bencana Alam Gempa Bumi Dalam Pembelajaran IPS SD
}

\author{
Lativa Qurrotaini ${ }^{1}$, Novita Nuryanto ${ }^{2}$ \\ Universitas Muhammadiyah Jakarta \\ email: Qurrota22@yahoo.co.id
}

\begin{abstract}
This research is centered on the Implementation of Earthquake Natural Disaster Mitigation Education through social studies elementary school in Cirendeu 02 South Tangerang. This implementation is very important to minimize the number of fatalities that occur, given the recent earthquake disasters in Indonesia. The purpose of this study is to determine whether the implementation of earthquake disaster mitigation education in social studies in elementary school has been implemented well in schools. The method used by researchers is a descriptive qualitative method, by describing or analyzing an object that occurs in SDN Cirendeu 02 South Tangerang using several methods including interviews to find out the results of research conducted by researchers. The results of this study are that the implementation of mitigation education is carried out through programs inside and outside the classroom conducted with several approaches, strategies, methods, techniques and tactics. The handling system in SDN Cirendeu 02 is carried out in several stages, the first stage of the principal confirming to the homeroom teacher. Then the homeroom teacher evacuates to one by saving students from taking shelter to the nearest objects in the class, the second evacuation leads students out of the classroom and finally the third stage the homeroom teacher collects students at the meeting point until it is completely safe .
\end{abstract}

Keywords: Mitigation Implementation, Earthquake, Elementary School Social Science Learning

\begin{abstract}
Abstrak
Penelitian ini berpusat pada Implementasi Pendidikan Mitigasi Bencana Alam Gempa Bumi melalui pembelajaran IPS SD di SDN Cirendeu 02 Tangerang Selatan. Implementasi ini menjadi sangat penting untuk meminimalisir korban jiwa yang terjadi, mengingat akhir-akhir ini bencana gempa bumi sering terjadi di Indonesia. Tujuan penelitian ini adalah untuk mengetahui apakah implementasi pendidikan mitigasi bencana alam gempa bumi dalam pembelajaran IPS SD sudah telaksana dengan baik di sekolah. Metode yang digunakan oleh peneliti adalah metode kualitatif deskriptif, dengan menggambarkan atau menganalisa suatu objek yang terjadi di SDN Cirendeu 02 Tangerang Selatan menggunakan beberapa metode di antaranya metode wawancara untuk mengetahui hasil dari penelitian yang telah dilakukan oleh peneliti. Hasil penelitian ini yaitu bahwa implementasi pendidikan mitigasi dilakukan melalui program di dalam maupun di luar kelas yang dilakukan dengan beberapa pendekatan, strategi, metode, teknik dan taktik. Adapun sistem penanganan yang ada di SDN Cirendeu 02 yaitu dilakukan dengan beberapa tahap, tahap pertama dari kepala sekolah mengkonfirmasi kepada wali kelas. Kemudian wali kelas melakukan evakuasi ke satu dengan
\end{abstract}




\section{Qurrotaini \& Nuryanto}

menyelamatkan siswa berlindung pada benda-benda terdekat yang ada di dalam kelas, evakuasi ke dua mengarahkan siswa ke luar dari ruangan kelas dan terakhir tahap ke tiga wali kelas mengumpulkan siswa di titik kumpul sampai keadaan benar-benar aman.

Kata kunci :Implementasi Mitigasi, Gempa Bumi, Pembelajaran IPS SD

\section{PENDAHULUAN}

Pembentukan budaya sadar dan selamat bencana alam gempa tersebut, dapat dilakukan melalui pendidikan kebencanaan, antara lain dengan pembelajaran mitigasi bencana. Kesadaran dan pembelajaran tentang risiko bencana alam dan bahaya yang dapat mengancam, harus dimulai dalam pendidikan sejak awal, dan dilakukan secara berkelanjutan.

Sadar terhadap bencana alam berarti siswa mempunyai pengetahuan dan pemahaman tentang bencana alam. Kesiapsiagaan berarti siswa harus peduli terhadap kondisi lingkungan sekitarnya yang berpotensi bencana alam. Melalui kesadaran dan kesiapsiagaan tersebut diharapkan siswa mampu mengurangi ancaman atau menghindari bencana alam untuk mencapai tujuan pembelajaran mitigasi bencana alam maka para guru tidak hanya diharapkan mengembangkan aspek kognitif, tetapi juga harus mengembangkan aspek afektif dan psikomotorik siswa.

Mitigasi bencana alam gempa adalah serangkaian upaya untuk mengurangi resiko bencana, Baik melalui pembangunan fisik maupun penyadaran dan peningkatan kemampuan menghadapi ancaman bencana (Triutomo, dkk;2007). Berkaitan dengan hal tersebut, maka pembelajaran mitigasi bencana merupakan bagian dari upaya meningkatkan kemampuan masyarakat agar paham terhadap karakteristik bahaya, mengubah perilaku agar berkualitas, kualitas sumber daya alam tidak menurun, dan meningkatkan kemampuan dalam menghadapi ancaman bahaya dari alam sejak dini.

Menurut Supriyono (2014:102) Mitigasi bencana gempa bumi merupakan istilah untuk menggambarkan upaya Pengurangan Risiko Bencana (PRB) gempa bumi.

Berdasarkan berbagai kejadian bencana alam di tanah air, maka kemampuan mitigasi bencana alam gempa sebaiknya diajarkan sejak dini, melalui pendidikan dasar. Sekolah dasar merupakan basis dari komunitas anak-anak, mereka adalah pihak yang harus dilindungi sekaligus perlu ditingkatkan pengetahuannya terkait mitigasi bencana alam. Oleh karena itu, maka pembelajaran mitigasi bencana alam pada anak-anak usia sekolah dasar, sangat strategis untuk dilaksanakan. Hal tersebut disebabkan pengetahuan tentang mitigasi bencana alam yang diajarkan sejak awal meningkatkan kemampuan anak-anak tersebut untuk waspada sebelum 
bencana alam, penyelamatan diri pada saat terjadi bencana alam, dan mengetahui kegiatan yang boleh dan tidak boleh dilakukan setelah bencana alam.

Dalam rangka mengurangi risiko bencana alam, hal penting dalam upaya mitigasi bencana adalah pengetahuan dan pemahaman tentang bencana alam serta kesiapsiagaan terhadap bencana alam. Hal tersebut diajarkan kepada siswa jenjang pendidikan Ilmu Pengetahuan Sosial atau biasa disebut dengan IPS (Qodariah dan Armiyati, 2013). Caranya adalah dengan mengintegrasikan dalam tema tertentu pada Kurikulum 2013. Penerapan pembelajaran mitigasi bencana pada tema yang sesuai pada mata pelajaran IPS merupakan upaya mendidik generasi muda yang sadar dan tangguh bencana alam dimasa depan atau masa yang akan datang.

Dinamika alam sangat memberikan dampak bagi kehidupan manusia, baik bersifat menguntungkan maupun merugikan inilah yang kemudian dikenal dengan sebutan bencana. Untuk meminimalkan risiko atau kerugian bagi manusia, perlu pengetahuan, pemahaman, kesiapsiagaan, keterampilan untuk mencegah, mendeteksi dan mengantisipasi secara lebih dini tentang berbagai macam bencana atau lebih dikenal dengan istilah mitigasi bencana. Mitigasi meliputi aktivitas dan tindakantindakan perlindungan bencana, berupa penyelamatan, rehabilitasi dan relokasi. Pengetahuan, pemahaman dan keterampilan berperilaku dalam mencegah, mendeteksi, mengantisipasi bencana secara efektif dapat ditransformasikan dan disosialisasikan melalui pendidikan IPS yang secara khusus membahas mengenai masalah tersebut.

Menurut

Saidihardjo

(2005:109) menyatakan Ilmu Pengetahuan Sosial merupakan program pendidikan yang berupaya mengembangkan pemahaman siswa tentang bagaimana manusia sebagai individu dan kelompok hidup bersama dan berinteraksi dengan lingkungannya baik fisik maupun sosial. Pembelajaran Ilmu Pendidikan Sosial bertujuan agar siswa mampu mengembangkan pengetahuan, sikap, dan keterampilan sosial, yang berguna bagi kemajuan dirinya sebagai individu maupun sebagai anggota masyarakat.

Berdasarkan pendapat para ahli di atas dapat disimpulkan bahwa pembelajaran Ilmu Pengetahuan Sosial (IPS) mempunyai peranan penting dalam mengarahkan anak untuk dapat menjadi warga negara Indonesia yang demokratis, bertanggung jawab, serta warga dunia yang cinta damai.

Berdasarkan pengertian dan tujuan dari pendidikan IPS, tampaknya dibutuhkan suatu pola pembelajaran yang mampu menjembatani tercapainya tujuan tersebut. Kemampuan dan keterampilan guru dalam memilih dan menggunakan berbagai model, metode dan strategi pembelajaran senantiasa terus ditingkatkan agar 
pembelajaran Pendidikan IPS benarbenar mampu mengkondisikan upaya pembekalan kemampuan dan keterampilan dasar bagi peserta didik untuk menjadi manusia dan warga negara yang baik. Hal ini dikarenakan pembelajaran IPS di sekolah dasar pada dasarnya bertujuan untuk pengembangan pengetahuan, sikap, nilai-moral, dan keterampilan siswa.

Belajar dari pengalaman yang sudah terjadi dan menyadari letak geografis Indonesia yang rawan sekali gempa bumi, maka pendidikan mitigasi bencana harus menjadi bagian penting dari kegian belajar dan mengajar di sekolah pada kurikulum K 13 pada mata pelajaran Ilmu Pengetahuan Sosial. lmu Pengetahuan Sosial (IPS) merupakan salah satu mata pelajaran yang diberikan di sekolah dasar yang mengkaji seperangkat peristiwa, fakta, konsep, dan generalisasi yang berkaitan dengan isu sosial. Mata pelajaran Ilmu Pengetahuan Sosial (IPS) di dalamnya memuat materi geografi, sejarah, sosiologi, dan ekonomi.

Oleh karena itu, rancangan pembelajaran guru hendaknya diarahkan dan difokuskan sesuai dengan kondisi dan perkembangan potensi siswa agar pembelajaran mitigasi bencana gempa bumi yang dilakukan benar-benar berguna dan bermanfaat bagi siswa, sehingga mereka mampu menjadikan apa yang dipelajarinya sebagai bekal dalam memahami bagaimana cara menyelamatkan diri ketika bencana itu sedang terjadi.
Berdasarkan uraian di atas peneliti mengambil judul "Implementasi Pendidikan Mitigasi Bencana Alam Gempa Bumi dalam Pembelajaran IPS SD". Tujuan diadakannya penelitian ini yaitu untuk mengetahui apakah implementasi pendidikan mitigasi bencana alam gempa bumi dalam pembelajaran IPS SD terlaksana dengan baik di sekolah dan juga yang tidak kalah penting yaitu untuk meningkatkan kesadaran menyelamatkan diri saat terjadi bencana alam gempa bumi di lingkungan Sekolah Dasar.

\section{METODE PENELITIAN}

Menurut Sugiono (2015:224) teknik pengumpulan data merupakan langkah yang paling strategis dalam penelitian karena tujuan utama dari penelitian adalah mendapatkan data.

Metode yang digunakan adalah penelitian kualitatif deskriptif yaitu metode penelitian yang digunakan untuk mendeskripsikan seluruh gejala atau keadaan yang ada pada saat penelitian yang dilakukan dan penelitan semacam ini menghasilkan laporan-laporan yang hanya bersifat umum.

Menurut Sujarweni (2014:32) observasi merupakan suatu kegiatan mendapatkan informasi yang diperlukan untuk menyajikan gambaran rill suatu peristiwa atau kejadian untuk menjawab pertanyaan penelitian, untuk membantu mengerti perilaku manusia.

Berdasarkan permasalahan yang diobservasi dan informan yang diwawancarai. Desain penelitian ini 
akan mencari tau terlebih dahulu bagaimana implementasi pendidikan mitigasi bencana dalam pembelajaran IPS di SDN Cirendeu 02. Pada penelitian ini juga akan memberikan usulan implementasi pendidikan mitigasi bencana terhadap pembelajaran IPS di SDN O2 berdasarkan kondisi internal dan eksternal pembelajaran sekolah tersebut.

Oleh karena itu maka peneliti mengambil sampel subjek penelitian ini adalah siswa siswi di sekolah SD Negeri Cirendeu 02. Merujuk pada sampel dalam Mukhtar (2013:94) dimana sampel kualitatif sebanyak $5 \%$ sampai dengan $10 \%$ maka peneliti mengambil sampel $10 \%$ dari 33 Siswa. Subjek yang di teliti 5 siswa dan wali kelas 5 pada kelas tersebut

\section{HASIL DAN PEMBAHASAN}

Berikut dalah beberapa hasil wawancara kepada pihak sekolah (1.)“Apakah sekolah sudah sistem peringatan bencana?"

Jawaban: Sudah, itu merupakan proses yang terintegrasi dengan beberapa mata pelajaran seperti IPA, IPS dan juga bekerja sama dengan lembaga lain. Misalkan BNPB daerah dan basarnas yang terkait dalam kebencanaan.

Berdasarkan jawaban tersebut

dapat disimpulkan bahwa sekolah sudah melakukan sistem peringatan bencana melalui beberapa mata pelajaran yang ada di sekolah seperti Ilmu Pengetahuan Sosial dan Ilmu Pengetahuan Alam. Selain itu juga pihak sekolah telah bekerja sama dengan Badan Penanggulangan

Bencana Daerah dan basarnas ataupun komonitas yang terkait di dalam kebencanaan.

(2)“Apakah pihak sekolah menerapkan pendidikan mitigasi bencana kepada peserta didik?"

Jawaban: iya, karena pendidikan kebencanaan atau mitigasi bencana merupakan pembelajaran yang sudah terintegrasi dalam kurikulum 13 terutama dalam pembelajaran Ilmu Pengetahuan Sosial dan Ilmu Pengetahuan Alam.

Berdasarkan jawaban tersebut dapat di simpulkan bahwa pihak sekolah telah menerapkan pendidikan kebencanaan melalui beberapa pembelajaran yang ter integritas dalam kurikulum 13, sehingga peserta didik dapat mempelajari pelajaran tersebut di sekolah.

(3)"Bagaimana cara bapak guru menerapakan pendidikan mitigasi bencana di sekolah?"

Jawaban: Ya, dengan cara memperaktekannya di sekolah. Bagaimana cara menyelamatkan diri dari bencana.

Berdasarkan jawaban tersebut dapat di simpulkan bahwa penerapan mitigasi bencana yaitu dengan cara memperaktekannya di sekolah supaya peserta didik dapat belajar bagaimana cara-cara menyelamatkan diri sehingga dapat siap siaga ketika bencana tersebut terjadi.

(4)"Apakah bapak guru menerapkan pembelajaran pendidikan bencana alam gempa bumi salah satunya melalui pembelajaran IPS?" 


\section{Qurrotaini \& Nuryanto}

Jawaban: Iya, karena pembelajaran IPS atau yang bisa disebut Ilmu Pengetahuan Sosial merupakan salah satu mata pelajaran yang terintegritas untuk memberikan pembelajaran tersebut.

Berdasarkan jawaban tersebut dapat disimpulkan bahwa pembelajaran pendidikan bencana alam gempa bumi sudah di terapkan di sekolah.

(5)"Pendekatan apakah yang bapak gunakan ketika mengajarkan pendidikan mitigasi bencana alam gempa bumi dalam pelajaran IPS?"

Jawaban: pendekatan yang saya gunakan ketika mengajar materi tersebut saya menggunakan pendeketan realistik. Dimana pendekatan ini menampilkan hal-hal yang nyata sesuai dengan karakteristik mata pelajaran yang sedang diajarkan. Semisal bagaimana ketika menyelamatkan diri atau halhal lain yang bersangkutan dengan materi yang diajarkan. Sementara untuk strategi pembelajaran dalam konteks ini biasanya menggunakan strategi ekspositori dimana strategi ini berorientasi kepada guru dengan demikian peserta didik dipersiapkan secara sistematik untuk menyimak pembelajaran ketika pembelajaran tersebut berlangsung.

Berdasarkan jawaban tersebut dapat disimpulkan bahwa guru atau selaku wali kelas menggunakan strategi pembelajaran ekspositori dan pendekatan realistik. Pembelajaran ini mengajarkan kepada peserta didik utuk menyimak atau memperhatikan pembelajaran yang berlangsung sementara untuk pendekatan wali kelas menggunakan pendekatan realisitk, pendekatan ini mengajarkan hal yang nyata yang sedang di pelajari oleh siswa.

(6)"Apakah sekolah pernah terkena gempa bumi?"

Jawaban: Pernah, pada pertengan tahun ini. Gempa bumi ini juga mengakibatkan plafon salah satu kelas jebol dan kaca jendela pecah,

Berdasarkan jawaban tersebut dapat di simpulkan bahwa sekolah memang pernah terkena gempa bumi. Yang menyebabkan plafon pada salah satu kelas jebol dan kaca jendelanya pecah. Gempa bemi ini terjadi dengan getaran yang cukup besar hingga menyebabkan hal tersebut terjadi.

(7)"Apakah bapak guru sudah bisa menyelamatkan diri atau membantu peserta didik ketika bencana tersebut terjadi?"

Jawaban: Insya Allah sudah siap, biasanya disini atau disekolah ini dalam 6 bulan sekali rutin diadakan simulasi tentang bagaimana penangan kebencanaan terutama gempa bumi.

Berdasarkan jawaban tersebut dapat di simpulkan bahwa bapak guru Insya Allah sudah siap untuk menyelamatkan diri karena setiap 6 bulan sekali rutin diadakan simulasi tentang penanganan bencana gempa bumi.

Dari semua narasumber yang di wawancarai dapat menghasilkan data bahwa mitigasi bencana merupakan tindakan-tindakan yang dilakukan menyelamatkan diri ataupun untuk mengurangi dampak yang ditimbulkan dari bencana 
tersebut. Mitigasi bencana telah terimplementasi di SD dengan baik melalui pembelajaran IPS. Mitigasi bertujuan untuk upaya penyuluhan kepada masyarakat dan warga di sekitar sekolah terhadap permasalahan bencana yang terjadi. Interprestasi hasil penelitan yang penulis maksud disini adalah hasil akhir dari analisis data yang kemudian ditafsirkan dengan interprestasi data. Penelitian yang dilakukan merupakan penelitian yang bermakna sehingga peneliti akan menafsirkan hasil penelitian secara keseluruhan. Peneliti akan menafsirkan dari beberapa teknik pengambilan data yang digunakan.

Berdasarkan hasil penelitian yang didapat dari hasil wawancara dan observasi, maka telah didapatkan hasil, subjek penelitian ini mengenai implementasi pendidikan mitigasi bencana gempa bumi di SDN Cirendeu 02 Tangerang Selatan sudah terimplementasi melalui pembelajaran IPS pada materi kebencanaan dan sudah ada pelatihan simulasi di sekolahan tersebut. Namun terkendala dalam fasilitas evakuasi karena hanya tersedia satu jalur dan satu lapangan yang tidak cukup untuk menampung orang-orang di sekolahan tersebut. Sekolah tersebutpun pernah melakukan pelatihan bagaimana mengimplementasikan mitigasi bencana alam gempa bumi dengan BNPB daerah. Pelatihan ini di lakukan kepada guru, sementara pelatihan kepada siswa atau peserta didik dilakukan oleh guru masing- masing atau wali kelas yang bersangkutan.

Pada tahun sebelumnya tepatnya tahun 2019 lalu sekolah tersebut beberapa kali terkena bencana grmpa bumi, hanya saja ada yang berkekuatannya tinggi dan ada pula kekuatan gempanya rendah. Gempa bumi yang berkekuatannya cukup tinggi menyebabkan plafon sekolah pada salah satu kelas jebol dan kaca jendelannya pecah di karenakan bangunan fisik gedung sekolah yang di bangun atau sarana dan prasarananya kurang mampu menahan getaran yang diakibatkan oleh gempa bumi.

\section{SIMPULAN}

Berdasarkan hasil penelitian, hasil analisis, hasil wawancara dan hasil observasi, serta hasil dari pembahasan yang akan menjawab dari rumusan masalah yang telah di analisis, maka implementasi pendidikan mitigasi bencana alam gempa bumi di Sekolah Dasar Negeri Cirendeu 02 Tangerang Selatan sudah terimplementasikan dalam pembelajaran IPS SD pada materi kebencanaan. Melalui pendekatan realistik dan strategi ekspositori, selain itu metode yang digunakan adalah metode ceramah dan metode demosntrasi dimana guru menerangkan lalu memperagakan pembelajaran yang sedang dilakukan sesuai materi pembelajaran. Sementara teknik yang digunakan yaitu teknik simulasi dimana peserta didik belajar untuk menyelamatkan diri melalui teknik tersebut. Dalam 


\section{Qurrotaini \& Nuryanto}

proses simulasi tersebut dilakukan beberapa taktik berupa berbaris dan berpegangan tangan serta mengikuti arahan dari guru untuk berjalan ke tempat yang lebih aman.

\section{DAFTAR RUJUKAN}

Futuruhu Farad. (2015). Mitigasi Bencana dan Penginderaan Jauh. Graha Ilmu. Yogyakarta

Khambali. (2017). Manajemen Penanggulangan Bencana. PT Andi. Yogyakarta

Sugiyono. (2014). Memahami Penelitian Kualitatif. Bandung: Alfabeta, CV.

Sujarweni, Wiratna V. (2014). Metodologi Penelitian. Yogyakarta: Pustaka Baru Press.

Supriyono Primus. (2014). Seri Pendidikan Pengurangan Risiko Gempa Bumi. C. V Andi Offset. Yogyakarta 